Meta

Journal des traducteurs

Translators' Journal

\title{
Pedagogical Considerations of Perspective Coherence Problems in Simultaneous Interpreting as a Result of Linguistic Structure, Illustrated by German-Korean Examples
}

\section{In-Kyoung Ahn}

Volume 50, numéro 2, avril 2005

Processus et cheminements en traduction et interprétation Processes and Pathways in Translation and Interpretation

URI : https://id.erudit.org/iderudit/011012ar

DOI : https://doi.org/10.7202/011012ar

Aller au sommaire du numéro

Éditeur(s)

Les Presses de l'Université de Montréal

ISSN

0026-0452 (imprimé)

1492-1421 (numérique)

Découvrir la revue

Citer cet article

Ahn, I.-K. (2005). Pedagogical Considerations of Perspective Coherence Problems in Simultaneous Interpreting as a Result of Linguistic Structure, Illustrated by German-Korean Examples. Meta, 50(2), 696-712.

https://doi.org/10.7202/011012ar
Résumé de l'article

En interprétation simultanée, si la structure syntaxique de la langue source (LS) et celle de la langue d'arrivée (LA) sont très différentes l'une de l'autre, les interprètes doivent attendre avant de pouvoir reformuler les segments de LS en expressions sensées dans la LA. Il est nécessaire d'adapter la structure de la LA à celle de la LS afin de ne pas augmenter indûment la charge de mémoire et pour minimiser le temps d'attente. Quoique cette adaptation facilite l'interprétation simultanée, elle intervient sur la cohérence perspective du texte. Découvrir le moment où cette perspective est atteinte et comment atténuer son effet peut aider les interprètes à améliorer leur performance. Cet article analyse les causes des atteintes à la cohérence perspective des énoncés en observant quelques exemples d'interprétation simultanée de l'allemand vers le coréen et propose des moyens pour réduire les problèmes, moyens qui doivent être étudiés et pratiqués avec les étudiants au cours de leur formation à l'interprétation professionnelle. 


\title{
Pedagogical Considerations of Perspective Coherence Problems in Simultaneous Interpreting as a Result of Linguistic Structure, Illustrated by German-Korean Examples'
}

\author{
IN-KYOUNG AHN \\ Hankuk University of Foreign Studies, Seoul, Korea \\ ahnik7741@hanmail.net
}

\section{RÉSUMÉ}

En interprétation simultanée, si la structure syntaxique de la langue source (LS) et celle de la langue d'arrivée (LA) sont très différentes l'une de l'autre, les interprètes doivent attendre avant de pouvoir reformuler les segments de LS en expressions sensées dans la LA. Il est nécessaire d'adapter la structure de la LA à celle de la LS afin de ne pas augmenter indûment la charge de mémoire et pour minimiser le temps d'attente. Quoique cette adaptation facilite l'interprétation simultanée, elle intervient sur la cohérence perspective du texte. Découvrir le moment où cette perspective est atteinte et comment atténuer son effet peut aider les interprètes à améliorer leur performance. Cet article analyse les causes des atteintes à la cohérence perspective des énoncés en observant quelques exemples d'interprétation simultanée de l'allemand vers le coréen et propose des moyens pour réduire les problèmes, moyens qui doivent être étudiés et pratiqués avec les étudiants au cours de leur formation à l'interprétation professionnelle.

\begin{abstract}
In simultaneous interpreting, if the syntactic structure of the source language (hereinafter $\mathrm{SL}$ ) and the target language (hereinafter $\mathrm{TL}$ ) are very different, interpreters have to wait before being able to reformulate the SL segments into a meaningful utterance in TL. It is inevitable to adapt the TL structure to that of the SL so as not to unduly increase the memory load and to minimize the pause. While such adaptation facilitates simultaneous interpreting, it results in damaging the perspective coherence of the text. Discovering when such perspective coherence is impaired, and how the problem can be attenuated, will enable interpreters to enhance their performance. This paper analyses the reasons for perspective coherence damage by looking at some examples of German-Korean simultaneous interpreting, and proposes means of reducing the problem which should be sought out and practised with students during interpreter training.
\end{abstract}

\section{MOTS-CLÉS/KEYWORDS}

communication between interpreters and end receivers, perspective coherence impairment, text progression, stylistic distortion, information reordering, prosodic devices

\section{Simultaneous interpretation and linguistic structure}

"Simultaneous interpreters have their own language!" This is the comment uttered jokingly by the moderator of a Korean television program regarding the profession of interpreter, a profession so admired by many. The comment actually signified much more than a lighthearted passing comment. Such a comment would only be evoked if something in the interpreter's rendition sounded strange or remarkable. 
Striking characteristics of the language of the interpreter in the booth for the general public might be, for example, certain prosodic features or unusual pauses which would not normally be found in monolingual texts. More attentive listeners would be able to detect unnatural choices in sentence syntax and in the progression of the text. Unatural phenomena occur with particular frequency in instances of simultaneous interpreting between two structurally quite divergent languages, as is the case with German and Korean.

Differences in language structure are primarily related to word order, which is dealt with in syntax, a sub-branch of linguistics, and syntax is often regarded as dealing with surface problems of language. However, word order is not merely a grammatical problem. It is not only related to semantics and the lexicon, but is also a means to process information in a language, and to achieve a particular effect. If the structural differences between the SL and the TT in a simultaneous interpretation are very great, the memory load for the interpreter can become too great and in such cases the word order in the TT must be sacrificed. The word order of the TL must be adapted to that of the SL to some extent. However, this adaptation results in idiosyncrasies in the TT in terms of syntactic, lexical and textual features, which are characteristic of interpreted texts and which represent discrepancies from a semantic, stylistic or textual perspective.

Kautz $(2000: 341,345)$ pointed out problems in simultaneous interpretation as a result of linguistic structure: he argues that the language structure of ST, as well as speech style and its contents, influences simultaneous interpreting. He maintains that interpreting from a SL with a regular linear structure of S-V-O, such as English and Chinese, is generally easier than interpreting from a SL such as German, which involves a considerable number of inflections and changes in word order. It is therefore said that teaching methodology needs to be different according to language combinations. He also mentions that in relation to different word order and memory load, an interpreter analyzes what comes into his/her ears by mobilizing his/her knowledge stored in long term memory, and stores it in short-term or working memory until s/he identifies meaning that can be reformulated into TT segment. Moreover, since s/he often has to reverse the order of the meaning unit when reformulating into TL, s/he needs to wait and store the 'meaning unit' until it is expressed with appropriate form and logic in the TL. However, as he further points out, the interpreter often cannot wait until a completed meaning unit has been delivered. It will be shown below that the wait for the meaning unit cannot be stretched indefinitely, as the memory load for the interpreter can be overtaxed and in the worst scenario, interpretation will no longer be possible. Alterations to the nuances or breaches of language norms, within acceptable bounds for the listener, are therefore frequently unavoidable, in order to enable simultaneous interpretation to take place at all.

Kalina $(1998: 25,114)$ also said that the role of linguistic factors cannot be overlooked in interpretation, noting that the language pairs and the direction of interpreting have different influences on the interpreters. She said that different interpreting strategies are therefore employed, depending on whether the word order of the language pair is similar or different.

The proposals made in this paper for overcoming the problems of simultanous interpreting caused by differences in linguistic structure should also be seen as inter- 
preting strategies. German belongs to the Indo-European language family, while Korean is an agglutinative language, which belongs to the Uralic language family. They have quite different word orders, and the problems which emerge from these language facts continuously pose enormous difficulties for interpreters. The difficulties arise particularly in compound sentences, in prepositional phrases and in all types of attributes which in German follow the expression to which they are attributed. This paper will focus on structurally conditioned problems of this sort which entail impairments to the coherence perspective of the texts and will analyze the reasons for these difficulties and offer some proposals for interpreter training related to these problems. First some background explanations for the concept of coherence in text linguistics will be provided, in order to introduce and define a new concept, e.g. 'perspective coherence' of a text.

\section{The concept of coherence in text linguistics and interpreting and translation studies}

In the mid-1960s, text emerged as a new unit of language. Since then, text came to be perceived as a grammatical unit transcending sentences, as an act, and/or a cognitive procedure, and these various aspects of text are the object of research. Whatever the focus of research, textuality, or the question of what it is that makes a text a text has always received much attention, and coherence has been regarded as a key property of textuality. The definition of text as "a sequence of coherent sentences"2 shows the importance of this concept. In other words, the key to a text is coherence. "Coherence is the precondition for a sequence of utterances to be understood as relevant text." 3

'Cohesion' is sometimes used in parallel with 'coherence.' Nowadays, cohesion is generally seen as surface grammatical relevance of text and coherence represents relevance in terms of substance. This distinction is largely influenced by Beaugrand and Dressler (1981). However, these two terms are not consistently used this way, nor have they been used as such from the beginning. Bellert (1970) does not see coherence as a mere intra-textual feature, but as meaning relations based on sense relevance as explicitly expressed in the text, and world knowledge, irrelevant to text, as perceived by the receiver.

On the other hand, Halliday and Hasan (1976) used the term 'cohesion' to refer to the relations of meaning that exist within the text, contrary to the current trend. Brown \& Yule (1983) attached importance to standard structures that transcend sentences such as proform and intonation. Petöfi \& Sözer (1989) said that coherence is a means of interpreting the relations between events in the text. Much research has been conducted on coherence in Romance and Slavic languages as well, ${ }^{4}$ but consistency in the use of the term is not found here either. As such, while coherence is the key factor in textuality, different scholars have different understandings and definitions of coherence.

Brinker ${ }^{5}$ resists the distinction between cohesion and coherence, suggesting an integrated concept of coherence. He argues that distinguishing these two concepts is unnecessary, as there is a close relationship between explicit (morphological-syntactic) forms of coherence, and implicit (semantic-cognitive) forms of coherence. He thus argues for separating the comprehensive concept of coherence into its difference 
aspects such as grammatical/thematic/pragmatic/cognitive coherence, or explicit/ implicit coherence. Böhler (1995: 113f.) also maintained that a distinction between cohesion and coherence is inappropriate as coherence involves the interaction between factors at several levels. Such concepts of coherence are very comprehensive, integrating the two concepts of cohesion and coherence with fuzzy borders between them. ${ }^{6}$

In interpreting and translation studies, coherence in target texts has on occasion been the object of research. Coherence of the TT can be the criteria against which to measure interpreting quality. Both ST and TT should be considered texts, and coherence is imperative in order to be considered as a text. In this regard, TT produced through interpreting and translation is not different from monolingual text.

Vermeer (1978) proposed a general theory for the generic concept of translatorial activity. Three of these general rules are the skopos rule, the coherence rule, and the fidelity rule. The rule of coherence or, to be precise, of intratextual coherence, stipulates that the target text must be comprehensible ('sufficiently coherent') for the intended users. ${ }^{7}$ Bühler's (1986) survey found that among the linguistic criteria for the evaluation of conference interpreting "sense consistency with original message" and "logical cohesion of utterance" were perceived as the most important. Following Heinrichs (1981), Böhler (1998) distinguished several levels of coherence and analyzed coherence features by giving examples of a particular literary translation. Gerzymisch-Arbogast (1999) examined the relations between coherence and the knowledge system that is presupposed in order to understand the text. More specifically, the study looked into the presupposed knowledge of ST readers and TT readers from different cultures and the resulting coherence of the text. GerzymischArbogast (2000) also discussed, in a comprehensive manner, how the study of textlevel problems can contribute to interpretation research, including coherence, theme-rheme, and isotopy. She mentioned that there are not many studies that associate interpreting with coherence, and that even fewer studies are conducted on actually applying coherence on interpreting. Gerzymisch-Arbogast (2000) refers to Shlesinger (1995) in her study of text surface coherence. Another concrete analysis can be found from Kusztor (2000). Her study found that TTs produced by interpreting show more coherence than STs, by more explicitly marking meaning relations.

Although there has not been very much research on coherence related to interpreting and translation, it is clear that coherence is an important element related to such areas as quality of interpreting and translation, characteristics of TT, analysis of difference between ST and TT, and the training of interpreters and translators. Gerzymisch-Arbogast (2000: 101f.) notes that while text is already established as a unit of translation in translation studies, the major trend in interpreting research to date involves interpreting procedure based on cognitive psychology. She goes on to mention Gile (1991: 155) who pointed out that studies of texts as a product of interpreting are few despite favorable conditions for such study. However, GerzymischArbogast also said that recently much attention has been given to the characteristics of text as the source and the product of interpreting, and that this may bring a paradigm change in interpreting studies.

The reason for the limited amount of research on text coherence and text as the product of interpreting may be not only the result of the fact that interpreting studies tend to take cognitive psychology as its major methodology, as Gerzymisch-Arbogast 
mentioned, but also that the concept of coherence is difficult to access in an analytical and systematic manner.

\section{Perspective coherence of text}

In this paper the concept of coherence will be taken as an all-encompassing concept, following Brinker $(2000,2002)$. The core concept treated here, e.g. 'perspective coherence of text' will be explained briefly in this section.

A broad range of modifiers are used for coherence such as 'syntactic,' 'grammatical,' 'semantic,' 'substantive,' 'logical,' 'pragmatic,' 'thematic,' and 'cognitive.' This is due to the lack of clarity in the definition of the term, and this in turn reveals that several complex aspects are subsumed under coherence. 'Perspective coherence,' discussed in this paper, cannot be easily explained invoking only one of the existing modifiers of coherence. This is due to the fact that these modifiers originated in text linguistic analyses of monolingual texts, where the impairment of perspective coherence is rarely encountered. The perspective coherence which is discussed here is connected with the expectation of the listener with respect to the unfolding text, including at the sentential level. When the listener cannot share the speaker's perspective regarding the unfolding text, the perspective coherence is impaired. In this sense, perspective coherence would be termed 'logical' or 'thematic' coherence.

This paper examines the target text produced by simultaneous interpreting in order to study coherence problems. The TT of simultaneous interpreting is influenced by ST and the SL, not only in terms of the contents, but also in terms of sentence structure. Between the languages with significantly different language structures, such as Korean and German, such influence may result in certain problems in the TT. Producers of original texts always have their own persepctive on the text they are creating. The speaker develops his thoughts in his own perspective and expresses them in the text. Likewise, text receivers will have their perspective on how the text will unfold, based on what they have received. This is true not only for the message of the text, but also for the linguistic form of the message.

In simultaneous interpreting, the interpreters become text producers for the final receivers. However, interpreters cannot have the same perspective as the original speaker. He has no control over the yet-to-be-revealed parts of the text being produced by the speaker, the text producer. The perspective of interpreters on the unfolding text is very limited. If the documents to be interpreted have been provided to the interpreter in advance, the intepreter's perspective at the micro-level, i.e. at the level of progression within the sentences and between the sentences, is more constrained than his/her perspective at the macro-level of the text. It is this limited perspective that this paper seeks to examine. Since the interpreter cannot control his/ her perspective on the text, $\mathrm{s} /$ he is sometimes not able to transfer the perspective of the speakers. When the speaker's perspective on text progression is changed by the interpreter, this impairs text perspective coherence. Such damage is expected to be greater as the language structure gap widens between the SL and TL, as is the case between German and Korean. In what follows, examples will serve as a basis for the discussion of the problems which can arise when the perspective of the interpreter cannot be matched to that of the speaker, and suggestions for alleviating these problems will be made. 


\section{Examples of perspective coherence impairment and suggestions for alleviation of the problems}

With respect to simultaneous interpretation between German and Korean, there are several differences in linguistic structure which present particular dangers for the impairment of perspective coherence. This discussion will be limited to a consideration of examples of conditional and relative clauses, and will cover the reasons for the impairment, the consequences of this impairment and suggestions for alleviation of the problems.

\subsection{Conditional clause}

In German, a conditional clause is a subordinate clause, and comes after a main clause, according to the standard word order. Standard word order refers to unmarked order in text. On the other hand, standard order in Korean holds that a conditional clause comes before a main clause. In this respect, the following German sentence $(1 \mathrm{G})$ can be translated into Korean as $(1 \mathrm{~K})$ :

(1G) (1)Der Chef wird Sie befördern, (2)wenn Sie die Lösung für dieses Problems finden

(1K) (2)dangsini i munjeui haegyeolchaegeul chajneundamyeon, (1)sajangnimi dangsineul seungjinsikil geosibnida. ${ }^{8}$

However, if $(1 \mathrm{G})$ is rendered in simultaneous interpreting, the language order can be changed as in $(1 \mathrm{~K}-1)$, in order to follow the German word order. Since this is a short and simple sentence, one does not encounter many difficulties in interpreting, and thus there is no need to adapt to the German word order when interpreting into Korean. This simple example, however, will be used first to illustrate the problem. There are numerous cases involving long or multi-level sentences which contain several subordinate constructions with the same basic structure as (1G), and under such circumstances, interpreting becomes very difficult if not impossible, unless the TL order is adapted to that of the SL. Therefore, to facilitate interpreting by adapting to the structure of ST, $(1 \mathrm{G})$ can be interpreted as follows:

(1K-1) (1)sajangnimi dangsineul seungjinsikil geosibnida. (2) dangsini i munjeui haegyeolchaegeul chajneundamyeon.

To look at the proposition alone, $(1 \mathrm{~K}-1)$ is the same as $(1 \mathrm{~K})$. However, $(1 \mathrm{~K}-1)$ is composed of two sentences, unlike $(1 \mathrm{~K})$. When a receiver listens to the first sentence of $(1 \mathrm{~K}-1)$, s/he would first think that the promotion is a given fact, without expecting a conditional clause to follow.

This is because such a structure is only used in a particular context in Korean. Therefore, when a conditional clause comes along as in $(1 \mathrm{~K}-1)$, the expectation of receivers is not met. Of course, speakers do talk that way at times in order to induce particular effects such as to arouse attention, or to ironically express that promotion will not be given. However, the original utterance of $(1 \mathrm{G})$ does not have this purpose. Therefore perspective coherence is damaged here. Moreover, the $(1 \mathrm{~K}-1)$ utterance is an incomplete sentence, thereby producing the unintended effect of a colloquial or poetic style. 
Dressler ( $\left.{ }^{3} 1991: 65\right)$ mentioned that it is difficult to recognize the illocutionary force of ST, in interpreting and translation, and to transfer it into TT, and that it is even more difficult to recognize and transfer perlocutionary force. The above example is a case in point.

There are certainly other ways of expressing the second sentence of (1K-1). Identifying and developing various ways of translation is one of the major tasks in training would-be interpreters. Here, two ways that end the second sentence of $(1 \mathrm{~K}-1)$ are introduced:

(1K-2) (1)sajangnimi dangsineul seungjinsikil geosibnida. (2)dangsini geu munjee daehan haegyeolchaegeul chajneundamyeon malibnida.

(1K-3) (1)sajangnimi dangsineul seungjinsikil geosibnida. (2)dangsini geu munjee daehan haegyeolchaeg-eul chajneundamyeon seungjinsikil geosibnida.

$(1 \mathrm{~K}-2)$ and $(1 \mathrm{~K}-3)$ both conclude the second sentence by using 'malibnida' and repeating the verb of the previous sentence 'seungjinsikil geosibnida,' respectively. While this eliminates the effect arising from an incomplete sentence, 'malibnida,' one of the typical expressions of simultaneous interpreting, sounds like a temporary expedient and gives a stylistic effect that is different from $(1 \mathrm{~K})$. The repetition of the verb also renders a different feeling compared to a compact sentence without repetition. These solutions are thus not entirely satisfactory, but in practical terms they are the best one can have recourse to if the goal is to simultaneously interpret complicated constructions such as that in $(1 \mathrm{G})$ into Korean. That the expressions in $(1 \mathrm{~K}-2)$ and $(1 \mathrm{~K}-3)$ have come to be known as 'interpreter expressions' is due to this structural difference.

When beginning training in simultaneous interpreting, students feel insecure because they do not know whether these problems which arise are of their own doing or whether they are structurally determined problems. It is therefore incumbent upon the instructor to clarify the structural nature of the problems and teach the realistic solutions, despite their shortcomings. In so doing it is very important that the instructor point out that the impact of the infelicitous solutions can be attenuated through the use of appropriate prosody. For example (1K-1) should not sound ironic and (1K-3) should not sound as if a special interpretation is to be inferred. Many students are sensitive to the fact that an expression such as 'malibnida' seems unnatural, but they are not sensitive enough to detect problems which arise from inappropriate prosody. It is the task of the instructor to sensitize them to these issues.

Example (1G) was artificially simplified, and now a more complicated example will be discussed which interpreters might actually encounter in the field. This will illustrate why adaptation to SL order is necessary in order to render interpreting.

(2G) (Morgen wird das letzte Spiel der Fußballweltmeisterschaft auf koreanischem Boden stattfinden. Da liegt es nahe, auch an die völkerverbindende Rolle des Sportes zu denken. Fröhliche und bunte Spiele hat Ihr Land zusammen mit seinen japanischen Nachbarn organisiert. Von dieser gemeinsam ausgetragenen Weltmeisterschaft geht eine Botschaft der Versöhnung aus: ) (1)Die Botschaft (2)heißt, (3)dass es im gegenseitigen Respekt und in Kenntnis einer gemeinsamen, oft leidvollen Geschichte (4)möglich ist, (5)gutnachbarschaftliche Beziehungen zu gestalten, 66wenn der Wille dafür vorhanden ist. 
(Das ist weltweit als ein Signal der Hoffnung verstanden worden. Ich wünsche mir für Sie, dass dieser Impuls auch über das Ende der Weltmeisterschaft hinaus erhalten bleibt.)

(2K) (1)geu mesijineun, (6)uijiman issdamyeon, (3)seolo jonjunghago manheun bubun gotongeulo jeomcheoldoen gongdongui yeogsaleul insighameulosseo (5) seonlingwangyeleul yeokkeonagal (4)su issdaneun (2)geosibnida.

(2G) can be naturally translated as (K2). ${ }^{9}$ Here, the conditional clause (6) in ST is located after the main clause following German standard word order. It is next to impossible for the interpreter to wait until s/he can place the conditional clause at the front as in $(2 \mathrm{~K})$. The interpreter cannot know if a conditional clause will come at the end, and even if a conditional clause is expected, s/he would not know when it comes, and thus cannot wait for it before rendition. Moreover, if $\mathrm{s} / \mathrm{he}$ does wait, the pause would be too long, and the memory load too heavy. Adding to the difficulties, word order and lexicon of (3) is quite complicated. Consequently, interpreters have to put the conditional clause at the end, like the word order of ST, as we have seen in example (1).

(2K-1) (1)geu mesijineun,3seolo jonjunghago manheun bubun gotongeulo jeomcheoldoen gongdongui yeogsaleul insighameulosseo (5)seonlingwangyeleul yeokkeonagal (4)su issdaneun (2)geosibnida. (6) uijiman issdamyeon malibnida.

(2K2) (1)geu mesijineun, (3)seolo jonjunghago manheun bubun gotongeulo jeomcheoldoen gongdongui yeogsaleul insighameulosseo (5)seonlingwangyeleul yeokkeonagal (4)su issdaneun, (6)uijiman issdamyeon geuleohge hal su issdaneun (2) geosibnida.

$(2 \mathrm{~K}-1)$ uses 'malibnida' as in $(1 \mathrm{~K}-2)$, and $(2 \mathrm{~K}-2)$ repeats the verb as in $(1 \mathrm{~K}-3)$. However, the repetition of the verb this time is a repetition through proform underlined in examples (2K-1) and (2K-2), above. These also impair the perspective coherence as was the case in example (1). The speaker is talking on a positive note, saying that the 2002 FIFA World Cup Korea/Japan can lead to reconciliation and friendship between Korea and Japan. Given that a third party is mentioning the sensitive and important issue of Korea-Japan relations, the interpreter may commit a serious mistake if the interpretation sounds like an ironic expression, contrary to the speaker's intention, by placing the conditional clause at the end without providing compensatory cues to aid the listener in parsing the intended meaning. In addition, the style of $(2 \mathrm{~K}-1)$ and $(2 \mathrm{~K}-2)$ is not appropriate to the text type of (2). This also fails to meet the expectations of the receivers.

In example (2), the conditional clause itself is short. However, since such conditional clauses can extend on and on, placing a conditional clause in front of a main clause in a Korean TT is not feasible in many cases. Moreover, conditional clauses are subordinate clauses, and thus the verb of the subordinate conditional clause comes at the end of the sentence in German, thereby further increasing the cognitive load on the interpreters. It is therefore unavoidable to use a word order such as that in $(2 \mathrm{~K}-1)$ or $(2 \mathrm{~K}-2)$, even if this word order entails impairment of the perspective coherence.

It is therefore even more important for the interpreter to be mindful of his/her pitch and stress patterns. Example (2) is a particularly illustrative example of the important role of prosody in the rendering of an acceptable version of the speaker's perspective. Students must be fully cognizant of the reasons for these problems and 
they must acquire the necessary flexibility through repeated and explicit exercises based on such examples.

\subsection{Relative clause $e^{10}$}

German relative clauses are a frequent source of problems for German-Korean simultaneous interpretation. A relative clause in German is a subordinate clause which modifies an antecedent, and is placed after the antecedent. The corresponding term for German relative clause in Korean is prenominal clause. ${ }^{11}$ Therefore, in most cases of German-Korean translation, relative clauses are translated into prenominal clauses. However, in Korean all modifiers come before the modifiee, and thus a relative prenominal clause should come before the modifiee, contrary to German.

(3G) (1) Jede Dolmetscherin, (2)die zu Hause einen Zwergschnauzer hat, (3ist in ihrem Beruf erfolgreich.

(3K) (2)jibeseo minieocheo syunaujeoleul kiuneun (1)modeun tongyeogsaneun (3jagi jigeobeseo seonggonghanda.

(4G) (1)Die Konferenzdolmetscher, (2) die von einer Sprache in eine andere simultan dolmetschen können, (3werden von vielen Leuten bewundert und beneidet.

(4K) (2)han eoneoeseo daleun eoneolo dongsie tongyeoghal su issneun (1)hoeui tongyeogsadeuleun (3)manheun salamdeului gyeongtangwa buleoumeul badneunda.

In examples (3) and (4), relative clauses in German are rendered as prenominal clauses in Korean. This way of translation produces a natural TT. However, for simultaneous interpreting, interpreters will have great difficulty in transferring a relative clause into a prenominal clause that modifies an antecedent, unless the relative clause is short and simple. This is because, as was seen in the examples of conditional clause, this way of translation would heighten the memory load, lengthen the pause, and at times make interpreting simply impossible. In order to prevent this situation, one usually has to bring the word order of TT, which entails altering the information order in line with German. Such adaptation can result in very awkward translation for certain relative clauses, and less awkward translation for other relative clauses.

Such variance occurs because some relative clauses are restrictive and some are appositive (non-restrictive). Many criteria are suggested for the distinction between these two: whether the relative clause is used to identify the referent of the antecedent (Behagel (1928: 767), Eisenberg (1988: 229)), whether the referent of the antecedent can be further limited (Lehmann (1984: 270)), closeness or looseness of relationship with the antecedent, etc. The variation in the terms and definition of restrictive and appositive relative clause reveals the difficulties related to stipulating the characteristics of relative clauses. Glinz (1994: 739) sees the distinction between the two not determined grammatically, but merely as a result of differentiating the text unit by the text producer in organizing the text. He argues that the receiver nevertheless identifies it as a whole. He thus said that whether a clause is restrictive or appositive is not a grammatical phenomenon, but a question of text organization. This has significant implications on the perspective coherence of TT.

Since the purpose of this paper does not lie in the classification and definition of the relative clause, focus will be paid primarily to its relevance to German-Korean simultaneous interpreting. To this end, the general criteria of explaining the two 
clauses, that is, whether the relative clause is required to identify the referent of the antecedent will be adopted. In terms of conveying information, this can also act as the key to determine whether relative clauses can be omitted during simultaneous interpreting under time constraint.

Successful communication requires that the receiver be able to figure out the referent denominated by the speaker. A restrictive relative clause limits the denotation of the referent of antecedent and thus is essential in identifying the referent. In order for a restrictive relative clause to be naturally translated, it is usually transferred as a modifier, i.e., prenominal clause in Korean, as shown in the following:

(3G) (1) Jede Dolmetscherin, (2) die zu Hause einen Zwergschnauzer hat, (3)ist in ihrem Beruf erfolgreich.

(3K) (2)jibeseo minieocheo syunaujeoleul kiuneun (1)modeun tongyeogsaneun (3jagi jigeobeseo seonggonghanda.

If the relative clause is del eted, a totally different meaning is rendered as follows:

'modeun tongyeogsaneun jagi jigeobeseo seonggonghanda.' (Jede Dolmetscherin ist in ihrem Beruf erfolgreich.)

In translating $(3 \mathrm{G})$ into Korean, placing the relative prenominal clause (2) in locations other than in front of the modifiee (1) will be impossible or very awkward. For example, $(3 \mathrm{~K}-1)$ has a totally different meaning compared to $(3 \mathrm{G})$.

$\left({ }^{*} \mathrm{~K}-1\right.$ ) (1) modeun tongyeogsaneun (2)jibeseo minieocheo syunaujeoleul kiuneunde (3)jagi jigeobeseo seonggonghanda. (Jede Dolmetscherin hat einen Zwergschnauzer zu Hause und ist in ihrem Beruf erfolgreich.)

On the other hand, the referent denoted by the antecedent of the appositive relative clause can be sufficiently identified without the relative clause, and the role of the appositive relative clause is to provide additional information for the referent. In this respect, even without the clause, communication is not seriously hampered. If the relative clause is deleted in example (4) as in (4'), the meaning of the sentence is not seriously distorted, assuming that the receiver has prior knowledge of what a conference interpreter is.

(4G') (1)Die Konferenzdolmetscher (3)werden von vielen Leuten bewundert und beneidet.

(4K') (1)hoeuitongyeogsadeuleun (3)manheun salamdeului gyeongtangwa buleoumeul badneunda.

Kim (1996) goes into detail about translating German relative clauses into Korean. As summarized in her last chapter, a German restrictive relative clause is almost always translated into modifiers in Korean, except in a few cases. On the other hand, an appositive relative clause is, in principle, translated into a prenominal clause as a modifier, but can also be translated into a separate sentence or into an adverbial clause. The questions which now raise themselves with respect to simultaneous interpreting are the following: first, whether German restrictive relative clauses can always be rendered as attributes, i.e. as prenominal phrases, and second, whether appositives can be translated into independent sentences or adverbial clauses without negative consequences. 


\subsubsection{Restrictive relative clause}

As seen above, a restrictive relative clause should be transferred into a modifier and therefore be located before the modifiee. If it is reformulated as an adverbial clause or a separate sentence, the main clause cannot maintain its significance, and overall, it becomes very awkward.

(5G) (1)Der Gewalt vorzubeugen und von Gewalt betroffenen Frauen Schutz und Hilfe zu bieten (2)sind (3)Aufgaben, (4) die der Staat besser als bisher wahrzunehmen hat.

(5K) (1)poglyeogeul yebanghago poglyeogui pihaeleul ibeun yeoseongege bohowa doumeul juneun geoseun (4) guggaga jigeumkkajiboda deo jal suhaenghaeya haneun (3)gwaje (2)ibnida.

If we assume a situation when the relative clause in example (5) cannot be transferred as a modifier, we would have no other choice but to make it into a separate sentence as in $(5 \mathrm{~K}-1)$ :

(5K-1) (1)poglyeogeul yebanghago poglyeogui pihaeleul ibeun yeoseongege bohowa doumeul juneun geoseun (3) gwaje (2)ibnida. (4)i gwajeneun guggaga jigeumkkajiboda deo jal suhaenghaeya habnida. (1)Der Gewalt vorzubeugen und von Gewalt betroffenen Frauen Schutz und Hilfe zu bieten (2)sind (3)Aufgaben. (4)Diese Aufgaben hat der Staat besser als bisher wahrzunehmen.)

However, the first sentence of $(5 \mathrm{~K}-1)$ is not a correct sentence. The receiver cannot understand what the speaker is trying to say when listening to the first sentence alone. The second sentence itself is not a non-sentence. Nevertheless, in order for the receiver to understand the whole message, $\mathrm{s} / \mathrm{he}$ has to integrate the two sentences to get the message across. In other words, after listening to the second sentence the receiver modifies the first sentence to correctly understand the speaker. In fact, it is assumed that this is what receivers actually do. All this is quite different from the analysis and inference involving receivers of monolingual text. The Korean TT inevitably distorts sentences and the way a text unfolds, and thus the receivers face a situation where they have to take a retrospective perspective in order to infer how the text should proceed. Again, the perspective coherence is significantly damaged. Example (5) is relatively short, and therefore a sentence such as (5G) could be translated into a natural Korean sentence without creating any of the described distortions, but we very often encounter cases where the restrictive relative clause cannot but be transferred into a separate sentence.

(6G) ([...] Vieles von dem, was wir gerne einfordern, nämlich wirtschaftliche und politische Integration, bei gleichzeitigem Erhalt der kulturellen und gesellschaftlichen Eigenheit, ist heute tatsächlich europäische Realität. Den Übergang von einem Staat zum anderen markiert oft gar kein Grenzbeamter mehr, sondern nur die Veränderung im Strassenbild, der Bauweise, der Kultur. Es gibt keinen Grund, zufrieden die Hände in den Schoss zu legen. Reformen der Institutionen sind notwendig, um die angestrebte Erweiterung der Union zu meistern, ohne an Handlungfähigkeit einzubüßen.)

(1)Aber (2)es gibt viele Gründe (3)für Respekt gegenüber der politischen Weitsicht und Lebensleistung der Verantwortlichen, (4)die nach der Katastrophe des Zweiten

Weltkriegs eine neue europäische Friedensordnung schufen.

(Ich bin überzeugt, dass Europa insoweit Vorbild sein kann. Auch in dieser Hinsicht lohnt sich der Weg auf den alten Kontnent [...]) 
(6K) (1)geuleona (5)ichadaejeon ihu saeloun yuleob pyeonghwajilseoleul changchulhan (4) chaegimjadeului (3)gin jeongchijeog anmoggwa ilsaenge geolchin eobjeoge daehan jongyeongsimeul (2)gajyeoya hal iyuneun manhi issseubnida.

In example (6), it is almost impossible to render an interpretation as in (6K). To wait until (5) comes, rendering it first, and then interpreting (4), (3) and (2) will increase the memory load too much. Moreover, (3) in German ST is rather complicated with prepositional phrases and possessives, which are also modifiers, but they are located after the modifiee, unlike the case in Korean. This further contributes to increasing the already heavy cognitive load of the interpreters and keeping all these stored in memory and then rendering the latter part of the ST segment first would be impossible. The remaining, rather sloppy way then is to interpret (1), (1), (3), (4) and then render (5) afterwards, as the following:

(6K-1) (1)geuleona (4)chaegimjadeului gin jeongchijeog anmoggwa ilsaenge geolchin eobjeoge daehan jongyeongsimeul (2)gajyeoya hal iyuneun manhi issseubnida. (5)geudeuleun ichadaejeon ihu saeloun yuleob pyeonghwajilseoleul changchulhaessseubnida. (1)Aber (2)es gibt viele Gründe (3)für Respekt gegenüber der politischen Weitsicht und Lebensleistung (4)der Verantwortlichen. (5) Sie schufen die nach der Katastrophe des Zweiten Weltkriegs eine neue europäische Friedensordnung.)

The first sentence of (6K-1) does not sound as ungrammatical and awkward as the first one in (5K-1). The sentence (5) in (6K-1) was originally a relative clause of the ST, but it is now a separate sentence in TT, and this sentence does not look very awkward either. At first glance, it does not seem to have any problem. However, a closer look reveals that this is not the case. Students are already quite happy if they have managed to reorganize the word order of the TT without the resulting sentences sounding deviant. In accomplishing this, they often overlook the textual problems.

First, the receivers, after having listened to the first sentence, cannot identify the 'Verantwortlichen (authorities)' even when going through the previous part of the text again. Only after listening to the second sentence can they figure out who they are. But it is not the intention of the speaker to arouse such curiosity. There is an even bigger problem: as the relative clause is separated into a new sentence, the 'Verantwortlichen (authorities)' are thematized. Thus, the receivers expect that the text will continue to talk about them, which it doesn't.

This phenomenon occurs because the relative clause is separated into an independent sentence. Kim (1996: 81) ${ }^{12}$ argues that a restrictive relative clause is subordinated to the main clause, and contains sub-information of the main clause information. She thus argues that as the relative clause is a subordinate clause; information contained in it does not become a theme in the text again. In the example $(6 \mathrm{~K})$, the relative clause becomes a new sentence and so the information that was contained in the previous relative clause in German becomes a theme in the TT. However, how the text is unfolded is obviously contrary to such expectations. The original speaker has a different perspective. The perspective coherence is damaged through interpreting. As such, a restrictive clause often results in awkward text progression and distorted style in German-Korean simultaneous interpreting. Such phenomena may also be easily found in other language pairs. A relative clause and the antecedent form a hierarchical order and establish an information unit (Kim (1996: 126)), but interpreting raised what was previously a subordinate information 
to the level of the information contained in the main clause. Here, we can see that the sentence form is deeply related to information ordering, and information reordering is associated with perspective coherence.

Two alternative intepretations are presented here. The first would be to interpret it as shown in $(6 \mathrm{~K}-1)$, in order to provide the listener with a point of reference as to the subsequent development of the text, e.g. that 'the authorities (die Verantwortlichen)' will not be a theme in subsequent utterances. The interpreter can assist the listener's understanding by allowing (5) to sound as much as possible like a supplementary commentary to the preceding proposition.

The second solution would be to rephrase (5) as in (6K-2):

(6K-2) (1)geuleona (4)chaegimjadeului gin jeongchijeog anmoggwa ilsaenge geolchin eobjeoge daehan jongyeongsimeul (2)gajyeoya hal iyuneun manhi issseubnida. (5)geu chaegimjalan ichadaejeon ihu saeloun yuleob pyeonghwajilseoleul changchulhan salamdeuleul malhabnida. (1)Aber (2)es gibt viele Gründe (3)für Respekt gegenüber der politischen Weitsicht und Lebensleistung (4)der Verantwortlichen. (5) Mit den Verantwortlichen meine ich diejenigen, die nach der Katastrophe des Zweiten Weltkrieges eine neue europäische Friedensordnung schufen.)

In this case, the second sentence in TT is more natural, but here again the perspective coherence is not preserved intact, as the danger is still present that the listener will have false expectations. Here again the interpreter can assist the listener to obtain the desired perspective coherence by uttering (5) in a casual tone as if it were a supplementary comment. By using such a tone, the interpreter conveys the sense that 'the authorities' will not be a theme in subsequent propositions.

\subsubsection{Appositive relative clause}

Based on example (4), it seems like appositive relative clause will not have the problems found in restricted relative clauses. Kim (1996) also discussed this matter as if there were no major problems in translating appositive relative clauses into separate sentences or adverbial clauses.

(7G) (Erst mit der Vereinigung, nachdem die Menschen gefordert sind, sich um sich selbst zu kümmern und für sich in der Fülle der Möglichkeiten einen eigenen Weg zu finden, äußert sich auch die vorhandene Grundstörung in entsprechenden Symptomen.) (1)Das (2)erklärt auch, (3)weshalb (4)ostdeutsche Menschen, (5)denen es materiell wesentlich besser geht als zu DDR-Zeiten, (6)nicht unbedingt glücklicher und zufrieden sind.

(Sie leiden an den neuen Lebensformen [...])

(7K) (1)ineun (5)dongdog sijeolboda muljiljeogeulo deo salgo issneun (4)dongdog salamdeuli (3)wae (6)kkog deo haengboghago deo manjoghaji anhneunga (2)do seolmyeonghaejubnida.

The appositive relative clause of $(7 \mathrm{G})$ can be transferred into a prenominal clause as in $(7 \mathrm{~K})$, but it is also possible to translate it into a concessive adverbial clause as in (7K-1). This still does not have a negative effect on the text progression, and keeps the text coherent.

(7K-1) (1)ineun (4)dongdog salamdeulI (5)dongdog sijeolboda muljiljeogeulo deo salgo issneundedo (3)wae (6)kkog deo haengboghago deo manjoghaji anhneunga (2)do seolmyeonghaejubnida. (1)Das (2)erklärt auch, (3)weshalb (4)ostdeutsche Mens- 
chen, (5)obwohl es ihnen materiell wesentlich besser geht als zu DDR-Zeiten, (6) nicht unbedingt glücklicher und zufrieden sind.

However, there are other cases:

(8G) (1)Den Westdeutschen (2)hat es an Respekt gefehlt (3)gegenüber (4)ihren östlichen Landsleuten und (5)deren Biographien, (6) die gezeichnet waren von vierzig Jahren autoritärer Parteiherrschaft und von den Folgen des zweiten Weltkrieges, denen sie ohne ausländische Hilfe - zum Beispiel dem in Westdeutschland wirksamen Marshallplan - ausgesetzt waren.

(Diese Respektlosigkeit hat dazu geführt, dass sich, aus verkürzter Sicht abegeschäzt, nur arme und reiche Deutsche gegenüberstanden.[...])

(8K) (1)seodog salamdeuleun (4)dongjjogui dongpodeulgwa (6)sasib nyeonganui jeonjejeog ildang dogjaewa ichadaejeonui gyeolgwaleul masyalpeullaengwa gateun oegugui doum eobsi geudaelo gyeokkeoya haessdeon (5)geudeului salmui yeogsae (3)daehan (2)jongyeongsimi eobseossseubnida.

In simultaneous interpreting, it is impossible to interpret the relative clause (6) of $(8 \mathrm{G})$ into the relative prenominal clause as in $(8 \mathrm{~K})$; it is not only long, but also very complex as (6) imbeds another relative clause and a parenthesis. Therefore, it is inevitable to separate the clause as in (8K-1):

(8K-1) (1)seodog salamdeuleun (4)dongjjogui dongpodeulgwa (5)geudeului salmui yeogsae (3)daehan (2jongyeongsimi eobseossseubnida. (6)geudeuleun 40nyeonganui jeonjejeog ildang dogjaewa ichadaejeonui gyeolgwaleul masyalpeullaengwa gateun oegugui doum eobsi geudaelo gyeokkeoya haessdeon geosibnida. (1) Den Westdeutschen (2)hat es an Respekt gefehlt (3)gegenüber (4)ihren östlichen Landsleuten und (5)deren Biographien. (6) Sie mussten vierzig Jahre lang unter autoritärer Parteiherrschaft und unter den Folgen des zweiten Krieges leiden, denen sie ohne ausländische Hilfe - zum Beispiel dem in Westdeutschland wirksamen Marshallplan - ausgesetzt waren.)

If the relative clause is interpreted as a separate sentence in TT as in $(8 \mathrm{~K}-1)$, the sentence itself is quite natural. ${ }^{13}$ But the problem occurs in the progression of the text. If interpreted like ( $8 \mathrm{~K}-1)$, receivers come to expect that the text would continue with the history of the lives of East Germans. However, ST actually thematizes the lack of respect. Thus, perspective coherence of the text is damaged. It is the same problem as was encountered in restrictive relative clauses. This may be because an appositive relative clause also contains information subordinate to the main clause as does a restrictive relative clause. ${ }^{14}$

What is different is that sub-information of an appositive clause seems to form various logical relations with the main clause compared to a restrictive relative clause, which may explain cases like the one we saw in (7K-1). In example (7), if the appositive relative clause can be transferred into an adverbial clause based on the logical relations, then this is also applicable to SL. Nevertheless, the speaker chose the relative clause, and this decision must have been based on his/her consideration of text progression, the effect on style, the organizational relationships between the information propositions, and the impact of such style on the receivers. If such relations are distorted or lost through interpreting, this can explain one of the reasons for the loss of illocutionary and perlocutionary force by interpreting as mentioned by Dressler ( $\left.{ }^{3} 1991: 5\right)$. 
In interpreter training solutions which compensate for such losses should be proposed and jointly sought. It is doubtful that a complete schematic-systematic presentation of such solutions can ever be achieved, however. It is important to find and apply solutions each time a problematic case arises during interpreter training because this will lead to a lightening of the memory load on the interpreter and will allow simultaneous translation to be accomplished between two languages which are so structurally divergent as German and Korean, in addition to which such solutions can compensate for losses at the textual level.

\section{Concluding remarks}

In simultaneous interpreting between two structurally quite different languages it is unavoidable that the TL will be adapted to the SL. In so doing, however, the perspective coherence of the text is impaired and the style is distorted. This is not to say that simultaneous interpreting is impossible or that it is not credible due to inappropriate information reordering. Interpreters in the field can lessen impairment of text perspective coherence or stylistic distortion by employing various strategies such as intonation, changes in the sentence form or through paraphrasing.

One interesting point is that it is not only the interpreters who attenuate perspective coherence impairment. It is expected that receivers also make a contribution. Text perspective coherence impairment and stylistic distortion do not occur in the TT as a whole, but occur partially where reformulating segments of ST structure into TT in its most appropriate form is impossible. Therefore, from the point of view of receivers, text progression is hampered or becomes awkward only occasionally as the text proceeds. Even in such circumstances receivers will soon convert their instantaneous confusion to better understanding of the text. Interpreters, for their part, try to induce the receivers toward such a direction. In this respect, the level of communication between interpreters and receivers differs from that between the ST speaker and the ultimate receivers. This can be seen as Grice's (1975) cooperative principle.

This paper explains text coherence impairment based on structural problems by giving examples of conditional and relative clauses. However, there are many other structural problems associated with German-Korean simultaneous interpreting. Thus adaptation to the SL through reorganization of the information, at the expense of the perspective coherence of the text is unavoidable. It is imperative, however, to maintain a high degree of communicative effectiveness with the end receivers by conveying nuances of intended meaning through prosodic devices.

In preparing students for simultaneous interpreting, teachers should raise the students' awareness of such structural problems, suggest and discuss various strategies to reduce distortions, thereby providing the students with resources to flexibly cope with such challenges.

\section{NOTES}

1. This work was supported by the 2004 Research Fund of Hankuk University of Foreign Studies.

2. Isenberg (1970: 1). Also refer to Steinitz (1968: 247), Steinitz (1969: 146), Dressler (1970: 64ff.), Harweg ( $\left.{ }^{2} 1979: 11\right)$.

3. Conrad (ed.) (1995: 118): “Die K[ohärenz] ist Voraussetzung dafür, dass eine Äußerungsfolge als zusammenhängender Text verstanden wird.” 
4. Refer to Pérennec (2000: 148ff.), Mazure (2000: 157).

5. Brinker $\left({ }^{5} 2000: 18\right.$, footnote 18$)$.

6. Refer to Rickheit \& Schade (2000), Bußmann (²1990: 388).

7. Quoted from Pöchhaker (1993: 88f.).

8. For the romanization of Hangeul (the Korean alphabet), the official transcription guidelines published in 2000 by the Korean Ministry of Culture and Tourism were used.

9. The Korean examples in the paper were translated by the author. The translation focused on visually enhancing understanding of the examples.

10. For a discussion of the problems of relative clauses in simultaneous interpretation between German and Korean, see Ahn (2002).

11. Kim (1996: 36ff.), Lehmann (1984): Refer to 70ff. (explanation of Japanese relative clause).

12. Refer to Bartsch (1978: 8), Hartmann (1984: 313).

13. Here the designated subject of the second sentence of the TT is not, ihre Biographien,' but, sie' (=the East Germans), which entails the use of a different verb. Given the different semantic-syntactic forms of expression in the two languages, this is an operation which is often necessary in order to render the sentence in Korean as natural as possible and in order to keep it short.

14. Refer to Hartmann (1984: 313f.).

\section{REFERENCES}

Aнn, I. (2002): tegseuteuui gwanjeomeseo bon doghan dongsitongyeogeseoui gwangyemun munje, Tegseuteueoneohag 11, p. 183-212. [Анм, I. (2002): Relative clause in simultaneous interpreting from German language into Korean language in the aspect of text, in: Text Linguistics 11, p. 183-212].

BARTsCH, R. (1978): Satzreihung, Satzgefüge oder Adverbialkonstruktion? Über pragmatische und kontextuelle Unterschiede zwischen semantisch gleichwertigen Aussagen, in D. HARTMANN \& H. Linke \& O. Ludwig. (eds.) (1978): Sprache in Gegenwart und Geschichte, Köln/Wien: Böhlau, p. 1-18.

De Beaugrande, R. A. \& W. Dressler 1981): Introduction into Text Linguistics, London: Longman. Behagel, O. (1928): Deutsche Syntax. Eine geschichtliche Darstellung. Bd. III (Die Satzgebilde), Heidelberg: Winter.

Bellert, I.(1970): On a Condition of the Coherence of Texts. In: Semiotica 2, p. 335-363.

BöHler, Christiane (1998): Die Analyse von Kohärenzmerkmalen am Text, Modell eines literarischen Übersetzungsvergleichs, angewandt und untersucht am Beispiel von Thomas Bernhards Roman "Holzfällen. Eine Erregung” und dessen Übersetzung ins Italienische, in: P. HolzER. \& C. Feyrer (Hgg.) (1998): Text, Sprache, Kultur: Festschrift zum 50jährigen Bestehen des Instituts für Übersetzer- und Dolmetscherausbildung der Universität Innsbruck. Frankfurt am Main/Berlin/Bern/New York/Paris/Wien: Lang, p. 109-123.

Brinker, K. ( $\left.{ }^{5} 2001\right):$ Linguistische Textanalyse. Eine Einführung in Grundbegriffe und Methoden, Berlin: Schmidt.

Brinker, K. (2000): Textstrukturanalyse, in: K. Brinker et al. (eds.) (2000): p. 164-175.

Brinker, K., Gantos, G., Heinemann, W. \& S.F. Sager (eds.) (2000): Text- und Gesprächslinguistik. Ein internationales Handbuch zeitgenössischer Forschung 1. Halbband (Linguistics of Text and Conversation. An International Handbook of Contemporary Research Vol. 1), Berlin/ New York: de Gruyter.

Brown, G. \& G. Yule (1983): Discourse Analysis, Cambridge University Press.

BüHLER, H.(1986): Linguistic (semantic) and extra-linguistic (pragmatic) criteria for the evaluation of conference interpretation and interpreters, in Multilingua 5 (1986) 4, p. 231-235.

Bussmann, H. ( $\left.{ }^{2} 1990\right)$ : Lexikon der Sprachwissenschaft, Stuttgart: Kröner.

ConRAD, R. (ed.) (1985): Lexikon der sprachwissenschaftlicher Termini, Leipzig: VEB.

Dressler, W. (1970): Modelle und Methoden der Textsyntax, in Folia Linguistica 4, p. 64-70.

Dressler, W. ( $\left.{ }^{3} 1991\right)$ : Der Beitrag der Textlinguistik zur Übersetzungswissenschaft, in Kapp, V. (ed.): Übersetzer und Dolmetscher, Tübingen: Francke.

Eisenberg, P. ( $\left.{ }^{2} 1989\right)$ : Grundriss der deutschen Grammatik, Stuttgart, Metzler. 
Gerzymisch-Arbogast, H. (1999): Kohärenz und Übersetzung: Wissenssysteme, ihre Repräsentation und Konkretisierung in Original und Übersetzung, in H. Gerzymisch-Arbogast, Gile, D., House, J. \& A. Rothkegel (eds.) (1999): Wege der Übersetzungs- und Dolmetschforschung, Tübingen: Narr, p. 43-54.

Gerzymisch-Arbogast, H. (2000): 'Text-bound interpretation': Zum Aufschlußwert der Textdimension für die Dolmetschforschung, in P. A Sснмітт (ed.) (2000): Paradigmenwechsel in der Translation. Festschrift für Albrecht Neubert zum 70. Geburtstag, Tübingen: Stauffenberg, p. 101-119.

GiLe, D. (1991): Methodological Aspects of Interpretation (and Translation) Research, in Target 3 (2), p. 153- 174.

GuInz, H. (1994): Grammatiken im Vergleich. Deutsch - Französisch - Englisch - Latein.Formen Bedeutungen - Verstehen, Tübingen: Niemeyer.

Grice, H. P. (1975): Logic and Conversation, Unpublished lecture notes, Partly published in P. Cole/ J. L. Morgan (eds.): Speech Acts (=Syntax and semantics 3), New York: Academic Press, p. 41-58.

Halliday, M.A.K. \& R. Hasan (1976): Cohesion in English, London: Longman.

Hartmann, D. (1984): Reliefgebung - Informationsvordergrund und Informationshintergrund in Texten als Problem von Textlinguistik und Stilistik, in: Wirkendes Wort 34, p. 305-323.

Harweg, R. ( $\left.{ }^{2} 1979\right)$ : Pronomina und Textkonstitution, München: Fink.

Kalina, S. (1998): Strategische Prozesse beim Dolmetschen: theoretische Grundlagen, empirische Fallstudien, didaktische Konsequenzen, Tübingen: Narr.

Kautz, U. (2000): Handbuch Didaktik des Übersetzens und Dolmetschens, München: Iudicium.

Kıм, B. (1996): Die deutschen Relativsätze und ihre Entsprechungen im Koreanischen, Frankfurt am Main: Lang.

Kusztor, M. (2000): Darstellung von Kohärenz in Original und Verdolmetschung, in S. Kalina, S. Buhl \& H. Gerzymisch-Arbogast (eds.) (2000): Dolmetschen: Theorie · Praxis · Didaktik - mit ausgewählten Beiträgen der Sarbrücker Symposien. Arbeitsberichte des Advanced Translation Research Center (ATRC) an der Universität des Saarlandes, St. Ingbert: Röhrig Universitätsverlag, p. 19-44.

Lehmann, C. (1984): Der Relativsatz, Tübingen: Narr.

Mazur, J. (2000): Textlinguistik im slawischen Sprachraum, in K. Brinker et al. (eds.) (2000): p. 153-163.

Pérennec, M. (2000): Textlinguistik im romanischen Sprachraum, in K. Brinker et al. (eds.) (2000), p. 145-153.

Pöchhacker, F. (1993): From Knowledge to Text: Coherence in Simultaneous Interpreting Translation and Knowledge, in Y. Gambier \& J. Tommola (eds.) (1993): Translation and Knowledge, SSOTT IV, Univ. of Turku: Center for Translation and Interpreting, p. 87-100.

Rickheit, G. \& U. Schade (2000): Kohärenz und Kohäsion, in K. Brinker et al. (eds.) (2000): p. 275-283.

SChlesinger, M. (1995): Shifts in Cohesion in Simultaneous Interpreting, in The Translator 1 (1), p. 193-219.

Steinitz, R. (1968): Nominale Pro-Formen, in W. Kallmeyer et al. (eds.) (1974): Lektürkolleg zur Textlinguistik, Vol. 2: Reader, Frankfurt am Main: Fischer, p. 246-265.

Steinitz, R. (1969): Adverbialsyntax, Berlin: Adademie Verlag.

Vermeer, H. (1978): Ein Rahmen für eine allgemeine Translationstheorie, in: Lebende Sprachen 23, p. 99-102. 